\title{
EU MACRO-REGIONAL STRATEGIES FOR THE BALTIC SEA REGION AFTER 2020. A NUTSHELL OF BEAUTY AND POSSIBILITIES
}

\author{
Jacek Zaucha1 ${ }^{1}$ iD , Dorota Pyć ${ }^{\text {iD }}$, Kai Böhme ${ }^{3}$ Lilia Neumann $^{1}$ (D) Dominik Aziewicz $^{1}$ (D) \\ ${ }^{1}$ Faculty of Economics, University of Gdańsk \\ Armii Krajowej 119/121, 81-824 Sopot: Poland \\ ${ }^{2}$ Faculty of Law and Administration, University of Gdańsk \\ Bażyńskiego 6, 80-309 Gdańsk: Poland \\ ${ }^{3}$ Spatial Foresight \\ 7, rue de Luxembourg, L-7330 Heisdorf: Luxembourg \\ jacek.zaucha@ug.edu.pl•dorota.pyc@prawo.ug.edu.pl•kai.boehme@spatialforesight.eu• \\ - lilia.neumann@ug.edu.pl•dominik.aziewicz@gmail.com
}

\begin{abstract}
The European Union Strategy for the Baltic Sea Region, that celebrates this year in Gdańsk its tenth anniversary, has been considered by many scholars and the decision makers as the model example of the soft governance that has gained in importance in the enlarged European Union (EU). The paper analyses the achievements and shortcomings of the Strategy from economic perspective with focus on externalities, public goods (also club goods, common-pool resources), economies of scale and scope and transaction costs. Two cases: Single Market for services and innovation spillovers are discussed more in depth. The analysis of these challenges and opportunities as well as the performance of the Strategy in the past and comparative analysis of its various evaluations allow authors to formulate several assumptions that should save the Strategy for the future. Their essence is related to mainstreaming of the Strategy into the EU and national policies (ensuring its stronger policy impact), strengthening strategic, visionary approach of the Strategy (e.g. facilitating large Baltic projects), better alignment with the business sector activities (understanding and addressing this sector expectations towards macro-regional co-operation) and acknowledgement of macro-regional solidarity as a foundation of the common efforts. Without all these, the Strategy might follow the case of the Baltic Development Forum that ceased to exist despite its evident positive effects for the entire region. Soft governance is difficult but promising as an alternative to the overgrowing sentiments towards centralisation. Thus, to avoid the impression of the 'Titanic ball' Gdańsk celebrations should provide a new start instead of the business as usual and manifestation of shallow self-satisfaction.
\end{abstract}

Keywords: macro-regional strategies, Baltic Sea Region, INTERREG.

\section{Introduction}

This paper has been developed to identify the most promising ways of continuing with the European Union Strategy for the Baltic Sea Region (EUSBSR) after 2020, bearing in mind Polish experience with implementation of the Strategy. EUSBSR is an example of the soft governance that has gained in importance in the enlarged European Union (EU). And, as the Strategy will celebrate its tenth anniversary this year, now is the right time to develop more insight into its current and future role 
in fostering development of the Baltic Sea Region (BSR) Furthermore, as the celebrations will take place in Gdańsk (Poland), there is a chance and duty to voice the opinions of Polish researchers at that occasion.

This paper mainly offers reasoning based on an economic perspective, in this way drawing on public economics and complementing other, more policy-oriented arguments (after Böhme, Zillmer, Hans, Antikainen \& Pyykkonen, 2016; Carlsen, Danielson, Gretskiy, Łada \& Puglierin, 2018; Ketels, 2009; Ketels, Pedersen \& Olsson 2017; Toptsidou \& Böhme, 2018). As the authors have been engaged for several years in BSR co-operation, their analysis based around public and institutional economics is combined with the fruit of participatory observation methods with a view to key assumptions on further implementation of the Strategy after 2020 being arrived at. In the conclusions section, Polish suggestions are set against BSR ones, hence the deliberate extending of the authorship here to allow for the engagement and utilisation of knowledge and experience derived from pre-deceasing evaluations of the EUSBSR.

\section{From transnational co-operation to macro-regional strategies}

From the outset, borders have been perceived as both obstacles and opportunities where the European project and European integration are concerned (ESPON, 2007, p. 7). Notwithstanding the introduction of the Single Market, borders continued to act as barriers to the free movement of people, goods and ideas. This was because of physical obstacles (a lack of roads, bridges or railway connections); underdevelopment of certain peripheral border regions; and mentality-related or cultural differences preventing more efficient pooling of the resources present on either side. Development synergies between cross-border regions were exploited insufficiently. Thus borders preserved or resulted in the retention if certain untapped development potential that would require some extra public intervention in order to be put into effect successfully. This has been the main reason for ongoing post-1987 efforts on the part of the Association of European Border Regions to convince the Commission and European Parliament to secure financing for the longterms projects that border regions pursue. Another reason might be the occurrence of common acute structural problems affecting the territories of several EU member states. For instance in 1985 the initiative involving the European Development Pole was launched by the Commission and the governments of France, Belgium and Luxembourg, as an answer to the crisis in the steel industry affecting regions of those three countries (CEC, 2015).

In 1990 the INTERREG Initiative was launched by the European Commission with 1.1 bn euro allocated and an exclusive focus on cross-border cooperation. It has since then evolved in terms of scope, priorities and financial resources (e.g. CEC, 2015; Medeiros, 2018), as depicted in Figure 1. The budget for the fifth (2014-2020) edition of INTERREG is ten times that of its 1990 predecessor, and consumes $2.8 \%$ of all cohesion policy allocations. In general the development of INTERREG can be seen as an evolution from the preparation of border areas for the opening of the Single Market (after Medeiros, 2018) to the acceleration of growth and development on various geographical scales through to cooperation beyond national borders. 


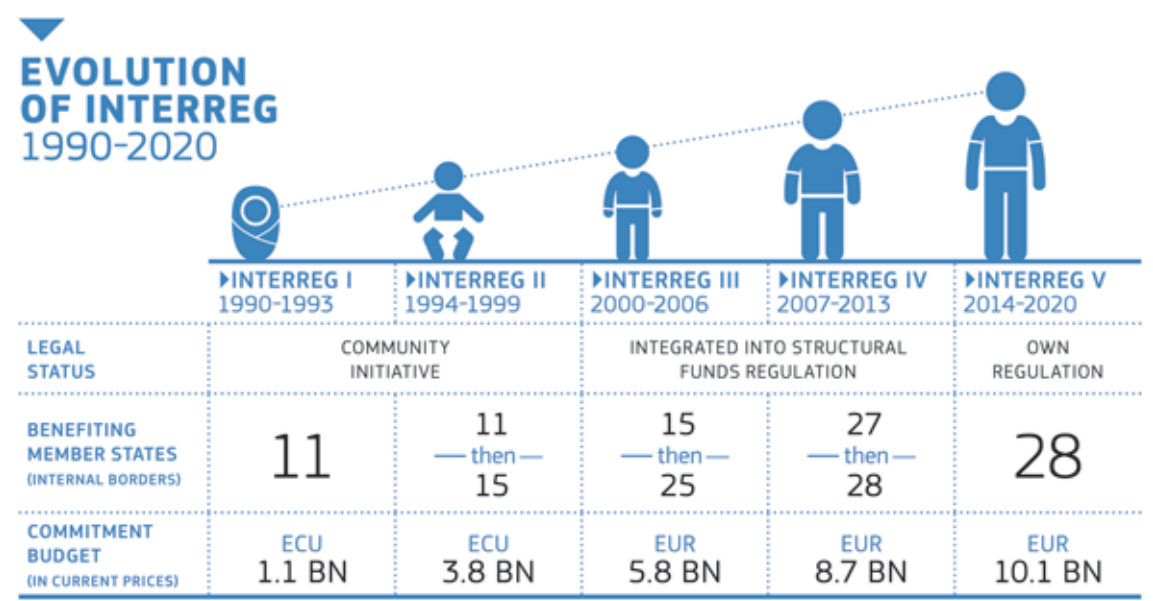

Figure 1. The evolution of INTERREG

Source: retrieved January 1, 2019 from https://ec.europa.eu/regional_policy/pl/policy/cooperation/ european-territorial/

In 1994, INTERREG was extended and divided into three strands covering cross-border cooperation, transnational cooperation and transnational energy networks. INTERREG III matured into the current (still-ongoing) architecture of three strands, i.e. cross-border cooperation (strand A), transnational cooperation (strand B) and interregional cooperation (strand C); whereas in 2007 INTERREG was mainstreamed into EU cohesion policy and the three strands were combined together under an EU cohesion objective named European Territorial Cooperation. In the current perspective (2014-2020) there is an allocation of 7.5 bn euro for strand A, whereas strand B has 2.1 bn. Effect is given to strand $B$ under 15 transnational co-operation programmes covering several countries $^{1}$. In fact, strand B involves so-called macro-regions, i.e. areas encompassing adjacent territories of several different countries or regions associated with one or more common features or challenges (Mirwaldt, McMaster \& Bachtler, 2011). EU Commissioner P. Samecki (2009) has been even more precise in this respect. For him, what is understood as a macro-region is 'an area including territory from a number of different countries or regions associated with one or more common features or challenges' (p. 1). The Commissioner continued by noting that: 'this carries no implication of scale: however, in an EU context a macro-region will involve several regions in several countries, but the number of Member States should be significantly fewer than in the Union as a whole' (p. 1). In the BSR context, the macro-region has been described as 'an area covering a number of administrative regions but with sufficient issues in common to justify a single strategic approach' (CEC, 2009, p. 5). Thus the need for a strategic approach seems to relate to the Baltic Sea macro-region.

INTERREG B seems well suited to supporting macro-regional activities. In financial terms at least, an important place among those strand-B programmes is taken by the Baltic INTERREG Programme covering: Denmark, Estonia, Finland, Latvia, Lithuania, Poland, Sweden and the northern parts of Germany, as well as partner countries Norway, Belarus and the north-western regions of Russia. The Programme has been functioning (under different names) since 1997. The

\footnotetext{
${ }^{1}$ Information on these Programmes is available on the website of the European Commission at: https://ec.europa. eu/regional_policy/en/policy/cooperation/european-territorial/trans-national/.
} 
first BSR Programme 1997-1999² was primarily focused on spatial planning, in close connection with the Vision and Strategies around the Baltic Sea (VASAB) ${ }^{3}$ initiative. In the next programming period 2000-20064, the scope was wider and economic development and ecological priorities were added. The current Programme has been focused on innovation, natural resources, sustainable transport and support for the EUSBSR. For the years 2014-2020, the Programme has been endowed with 282.4 million euro, to be spent on transnational projects (executed jointly by at least 3 partners from different countries).

However, macro-regional cooperation should not be limited to INTERREG B projects. As pointed out by Zaucha (2007), the BSR is formed from a dense network of various types of transnational cooperation initiative both formal and informal. According to Gänzle (2018), there are no fewer than 40 pan-Baltic organisations, such as VASAB ${ }^{5}$, the Union of the Baltic Cities (UBC), the Council of the Baltic Sea States (CBSS), the Helsinki Commission (HELCOM) and many others. In addition to that there are more than 600 organisations engaged in BSR affairs (Schymik, 2012). Zaucha (2013) underlines the impressive tradition of BSR cooperation initiated by the Nordic countries in the 1950s (i.e. the joint Nordic labour market, establishment of the right to settle in other Nordic countries and passport-free travel, and close collaboration between Nordic parliaments and Nordic governments). This experienced paved the way for intensive BSR co-operation after the fall of the Iron Curtain. There was some strategic thought on the part of the Scandinavian countries - behind the extension of the Nordic cooperation experience to the entire BSR.

This was supported by relevant research extending to the entire macro-region (EuroFutures, 1994; Kukk, Jervell \& Joenniemi, 1992; Statistiska Centralbyran, 1993). As Deike (2000) noted, a specific feature of Baltic integration is the perception of development opportunities for the macro-region in institutional and economic cooperation between Baltic countries, without exchange with the European core (Pentagon) being looked at. To a large extent, it was the political will that led to the transformation of the BSR concept into an element of reality in the 1990s. Scott (1998) even noted the emergence of a Baltic type of regionalism. Its essence is the formation of an independent Baltic-specific set of goals and aspirations, as well as the shaping of a public debate on how these goals and interests should be achieved. These activities have been of a bottom-up nature, and they have been engaged in by both national and local governments, as well as NGOs. Such a type of integration has required mainly networking connections, while formal arrangements (contracts, conventions) played a secondary role. Since then the mechanism as described above has been functioning without substantial modifications. BSR is considered as an 'innovation lab for governance' (Jetoo, 2018, p. 2).

Thus at the end of the first decade of the current century BSR co-operation was framed by various independent networks and financed from national sources and from EU funds - mainly the INTERREG B strand and some other programmes like TACIS or PHARE CBC. A question then arises almost naturally as to why in these circumstances the EU strategy for the macro-region was necessary. As Samecki (2009) pointed out, the main reason was the conviction that 'overall coordination of actions across policy areas will very likely result in better results than individual initiatives' (p. 1). Zaucha (2013) adds to that some other reasons, such as a perception of insufficient

\footnotetext{
$\overline{2}$ More details on this Programme are provided by Zaucha (1997), Zaucha \& Goermar (1998) and Zaucha \& Matczak (2007).

${ }^{3}$ Cooperation between ministers responsible for spatial planning and development in the BSR countries. For more details, see Zaucha \& Fischer (2009).

${ }^{4}$ For more details on Baltic INTERREG III B and its results, see Zaucha \& Matczak (2007) and Zaucha \& Szydarowski (2005).

${ }^{5}$ For the origin of VASAB see Zaucha (1998).
} 
progress with BSR integration perceived by key stakeholders in the region, the necessity of a longterm strategy for furthering the development of the macro-region, a need to integrate different sectors and certain horizontal actions and to set tasks stage by stage, as well as specific goals, the new political context for cooperation (e.g. EU enlargement), the lack of strategic use being made of EU funding available for the BSR, and unused potential for growth as well as a worsening of the state of the Baltic Sea environment. Moreover, Baltic INTERREG has never had an ambition to become a coordination platform and at a technical level, remained merely a source of project money (Zaucha, 2010, p. 122). A pan-Baltic coordination platform was therefore absent.

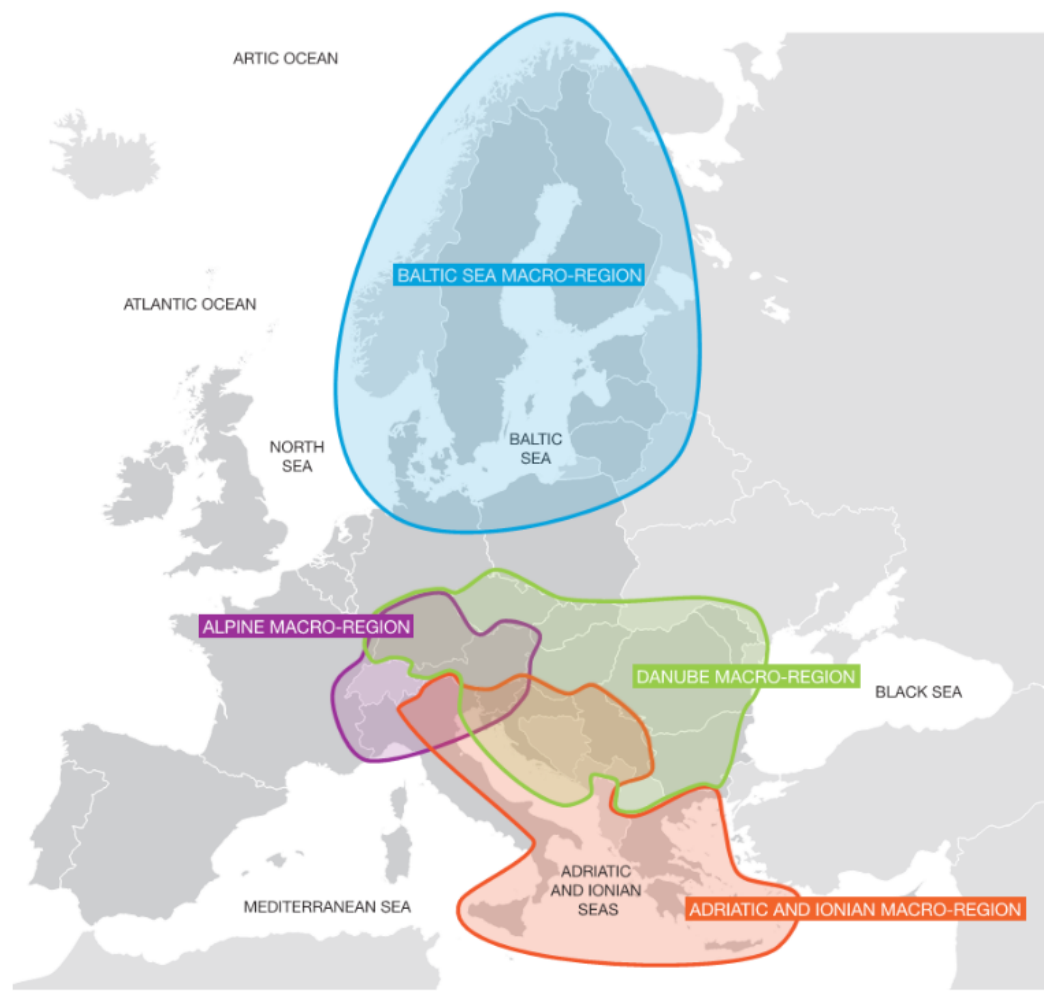

Figure 2. EU Macro-regional Strategies as of 2018 Source: CEC (2018, p. 5).

In 2007, the European Council in its Presidency Conclusions invited the Commission to prepare a EUSBSR. The BSR was chosen as a pilot area in the EU since many scholars see it as an icon of macro-regional co-operation (Karlsson, 2004). The EUSBSR was ready in 2009 and adopted by the European Commission in June 2009, and endorsed by the European Council in October 2009 (CEC, 2009) $)^{6}$. This is not a top-down document. It brings together cooperation of an intergovernmental nature (e.g. VASAB or HELCOM), as well as transnational (bottom-up) cooperation, and tries to match them with the framework of EU cohesion policy. Thus it does not take the place of existing networks and relations, but rather tries to capitalise on them as work with a more far-sighted approach and concerns is guided.

\footnotetext{
$\overline{{ }^{6}}$ The process of Strategy elaboration has been analysed in detail in the literature, e.g. Zaucha (2010).
} 
The successful deployment of the BSR pilot encouraged the Commission and the member states to replicate this experience in other EU macro-regions, and in particular in those with a high degree of self-identification. Consequently, the EU currently has four macro-regional strategies (Fig. 2), while an additional one for regions in the Carpathian has been pursued by the governments of several of the Central and Eastern European Countries. Strategies have been devised to 'address specific challenges and opportunities, and to promote mutual learning processes through 'experimenting' (Gänzle, 2018, p. 340). There have also been expectations as regards strengthened policy cohesion (cf. McMaster \& van der Zwet, 2016).

At first glance, this rush towards macro-regional strategies might be interpreted as a success for the strategic macro-regional approach taken in the EU. According to Böhme et al. (2017) territorial cooperation is not a luxury, but a must, in this day and age. Toptsidou, Böhme, Gløersen, Haarich and Hans (2017, p. 5) are of the opinion that 'macro-regional strategies can be driving forces for change if the right momentum is achieved'.

\section{A raison d'être for macro-regional cooperation in theoretical perspective - the case of the BSR}

According to major textbooks in international economics, integration between national economies can be attributed mainly to foreign trade and foreign direct investment (FDI). These offer a main motive for cooperation between states, leading to the formation of free-trade areas or custom unions covering several countries or parts thereof. However, the BSR pattern of integration through trade is complex to say the least. According to a European Commission report: 'compared to the EU average, the Baltic Sea Macro-region shows an above average integration intensity' (CEC, 2018, p. 39). But this is true for the EU part of the macro-region. Moreover, as Zaucha (2009) pointed out, mutual interconnection through trade is visible mainly in Scandinavian countries. As acknowledged in the same Commission report (CEC, 2018), two integration hubs can be observed inside the macro-region: one comprises the EU's three Scandinavian countries and Germany, and the second is made up of the three Baltic States, Poland and Germany. Thus, despite the fact that only part of Germany even falls within the BSR, that country is a main trading partner for both groups. This leaves integration through trade away from Scandinavia looking like a slightly artificial construct and concept. For their part, Baltic regions of Russia do not trade intensively with other BSR countries (with the exception of neighbours), and Belarus trades mainly with Russia. Mecklenburg-Vorpommern (a genuinely Baltic part of Germany) plays only a limited role in BSR integration through trade and FDI. Poland's Pomorskie region (an important BSR hub within Poland) does export intensively to Finland, Denmark, Sweden and Estonia, but then it also does the same to the UK, and even to Greece and Malta. Likewise, among exports from the adjacent Zachodniopomorskie region in Poland countries in the ranking of top trading partners after Denmark are Luxembourg, Cyprus and the Slovak Republic (Umiński, 2012).

However, as recent research makes clear, the main determinants of foreign trade in the case of the Polish regions relate to the gravity model and path dependency (Brodzicki \& Umiński, 2017). This might explain the importance of Germany and Sweden in BSR integration through trade, with attribution or non-attribution to the BSR possibly playing a secondary role. Many BSR countries have strong economic links (in terms of FDI) with partners outside the macro-region. In Poland, export-generating FDI in many cases locates in special economic zones, with countries 
of origin (partly) in the BSR confined to Germany. In contrast, the main sources of FDI in the Polish case are in fact the Netherlands, France, Spain, the UK and Austria (Nazarczuk \& Umiński, 2017).

All of this denotes that the origin of the phenomenon of a dense cooperation network in the BSR needs to be sought elsewhere than merely in trade and FDI. If we put aside for a while the cultural causes, those related to balance of power and international lobbying, and even the emotional effect of the fall of the Iron Curtain, what is left is an inclination to interpret the Baltic cooperation phenomenon in terms of externalities, public goods (also club goods, common-pool resources) and transaction costs (the cost of engaging in economic relations and processes).

One of the first pan-Baltic cooperation initiatives - the HELCOM - was launched even before the Iron Curtain fell, given the need to address the pressing problem of pollution in the Baltic Sea. This of course connected with the Sea as such - as a joint development resource and ecological gem from the point of view of all BSR countries. BSR cooperation was then instrumental in addressing the negative externality in terms of degradation of the Sea's environmental status that would otherwise have risked becoming a textbook case of the notorious problem of 'free-riding'. Joint macro-regional efforts to securing a more-favourable environmental status for the Baltic Sea can also be interpreted in terms of taking care of common-pool resources (characterised by rivalrous consumption coupled with the non-excludability of users), in order that a classic 'tragedy of the commons'might be avoided.

The BSR was also suffering from substantial accessibility bottlenecks in need of public investment. A success story is the $\emptyset$ resund Bridge, which gave an economic boost to the development of the Copenhagen-Malmo cross-border region, while via Baltica and rail Baltica still await their turn. The same situation applies to the concept of a pan-Baltic transmission grid that might connect the BSR North (as endowed abundantly with clean energy resources) with the BSR South that is struggling for energy security. Such developments would require supra-national coordination, not least given the frequent situation of their not proving profitable at single-country level (in Poland via Baltica mainly serves to connect Warsaw with the relatively small town of Suwałki). The benefit at macro-regional level accrues because BSR networking metropolises are founded (as a positive externality). The final result in terms of energy security, agglomeration economies or improved accessibility can also be seen in terms of genuine public or quasi-public goods.

As an example of positive externality (synergy), it is possible to take the Baltic Development Forum (BDF), as a think-tank and high-level network for business, politics and R\&D in the BSR, which facilitated public-private dialogue with a view to the potential for innovation, sustainable growth and competitiveness of the BSR being advanced, and the macro-region's visibility and reputation strengthened. In addition to organising conferences and meetings, the BDF each year published latest information on various aspects of the BSR's development, in that way facilitating important business and political decisions. Unfortunately BDF was closed in 2018. The UBC acts in similar way, by offering member cities a possibility of cooperation on concrete issues important to local government. This allows the latter to solve many local problems in a more effective and efficient way through exchange of know-how and experience (a positive externality).

Positive externalities in many cases require public cooperation to turn such synergies into reality. Maritime spatial development may serve as an example. Due to newly-emerged trends and concepts related to the so-called 'blue economy' (OECD 2016; Schultz-Zehden, Weig \& Lukic, 2019; Varjopuro et al., 2015; Zaucha 2018), the sea has come to be exploited more intensively recently. To avoid conflict (a negative externality) in regard to the use of marine space, maritime spatial planning has been introduced (cf. Ehler, Zaucha \& Gee, 2019). The Baltic Sea will be covered by such plans prepared by various countries under different legal regimes and with dif- 
ferent ambitions and goals in mind. EU guidance in this matter is very general (CEC, 2014). Only at the macro-regional level is there a possibility of a more concrete common denominator being agreed on, with a view to consistency of the planning effort within the sea basin limits being secured (Zaucha, 2014a). A lack of coordination among plans would hamper many marine industries, e.g. by increasing the costs of energy transmission, navigation or fisheries; but maritime spatial planning is an important process covering transaction costs of business entities becoming engaged in blue growth. For that reason, BSR countries decided on the commencement - in 2010 - of pan-Baltic coordination on maritime spatial planning by way of a VASAB - HELCOM Working Group (Zaucha, 2014b). This effort gained financial support from the BSR countries themselves, while the Working Group developed guidelines on transboundary consultations, public participation and cooperation that offer a framework for the concertation of planning efforts.

The most interesting case involves a mismatch between positive and negative externalities as regards scope and time. Some potential BSR synergies might never have occurred without public intervention if the private losses of businesses precede positive macro-level externalities. Two examples are presented below. The BSR is among the most innovative EU macro-regions. However, this innovative potential is concentrated mainly in Sweden, Denmark, Finland and Estonia (ESPON, 2012). The South BSR region is in contrast assigned to the two lowest categories, i.e. imitative innovation area or smart and creative diversification area. It seems that such a situation creates a potential synergy for Poland, Lithuania, Latvia or Mecklenburg-Vorpommern to benefit through more intensive co-operation on innovation ecosystems with a view to the innovative capacity of their businesses being increased. In reality this is not easy. Pure market-driven attitudes would prompt Scandinavian leaders to maintain their quasi-monopolistic power. For the BSR as such, the innovation spill-over would seem truly beneficial but it would lead to redistribution of costs and benefits among the countries and single businesses. Thus the micro- and macro-logic is contradictory. There is a need for a high-level political agreement to address such a challenge and cover transaction costs of a new arrangement.

A very similar situation applies with regard to a genuine Single Market for services. Although declared a cornerstone of EU integration, this has never been introduced in reality. In contrast, Western European countries fight against Eastern European contractors who offer construction or transport services at a much lower price due to their low-cost advantages. They are even accused of social dumping. The problem is in temporal mismatch. Services offered by cheap Eastern European contractors will in the long run increase the level of prosperity in the countries of their origin. As a result the prices of services will go up and a convergence process will occur. But this will take place at the expense of revenues of the construction or transport sector in the richer countries in a short run. Due to its natural and demographic features as well as structural transformation of Scandinavian economies (towards those of a knowledge-intensive nature), the BSR might offer more favourable circumstances for a piloting of the Single Market concept. But this would also require some political agreement, as in the case of innovation.

In summary, there are seen to be two types of issue that require macro-regional cooperation of public and private entities that goes beyond foreign trade and capital flows. The first relates to common-pool resources, public or club goods, positive and negative externalities, all of which might differ from one another but have in common the fact that they cannot be addressed at the level of the individual country. These are therefore duties typical for public authorities that must be performed at supranational level. The second issue relates to transaction costs whose coverage might trigger private-sector actions and self-reinforcing processes of development. This is a much more subtle type of intervention involving the steering of private interactions across national borders, 
with information revealed, confidence created, initial stages of interactions financed, and so on. Both type of issue prompting macro-regional cooperation require a certain amount of strategic backing and are properly recognised by a Commission describing the tasks of European Territorial Co-operation as follows: 'With its place-based focus, it is on the spot to solve problems that transcend boundaries and require a common approach. It is the key way of helping regions share their knowledge across Europe.' (CEC, 2011a, p. 9).

\section{The EU Strategy for the Baltic Sea Region}

The EUSBSR can be considered a kind of agreement between member states of the EU and the European Commission. This is not then a Commission instrument as such, but a cooperative platform between the Commission and EU BSR member states, with the latter playing a key role in substantiating and implementing a Strategy that proposes three objectives overall, with four sub-objectives each. These are:

1) Save the sea:

- Clear water in the sea,

- Rich and healthy wildlife,

- Clean and safe shipping,

- Better cooperation.

2) Connect the region:

- Good transport conditions,

- Reliable energy markets,

- Connecting people in the region,

- Better cooperation in fighting cross-border crime.

3) Increase prosperity:

- Baltic Sea region as a frontrunner for deepening and fulfilling the Single Market,

- EUSBSR contributing to the implementation of the Europe 2020 Strategy,

- Improved global competitiveness of the BSR,

- Climate change adaptation, risk prevention and management.

The Strategy is complemented by the Action Plan presenting an indicative set of priority areas under each pillar. The Plan is a living document that has been revised several times, and most recently in 2017 (CEC, 2017). The Action Plan addresses 13 Policy Areas (PA) and 4 Horizontal Actions (HA), as depicted in Figure 3.

The PA or HA are led and coordinated by one or two member states or by intergovernmental and/or non-governmental organisations. At country level there are National Contact Points to encourage national organisations to participate actively in the EUSBSR. But the key implementation vehicles are the projects and processes (named Flagships) that are run under each PA and HA. These projects and processes are usually of a bottom-up and grassroots nature, though some are initiated directly by PA or HA coordinators/leaders. But in many cases they are invented by stakeholders interested in their deployment, agreed with the coordinators/leaders of a relevant PA or HA and usually presented to various international or national financial institutions with a view to necessary funds for implementation being secured. PA Coordinators (and HA leaders) as a rule support flagship partners in their applications, by advising, or by finding additional partners for funding sources (Toptsidou \& Böhme, 2018). A majority of projects test certain pilot solutions or prepare the ground for necessary changes. The EUSBSR is based on 'the three No's', 


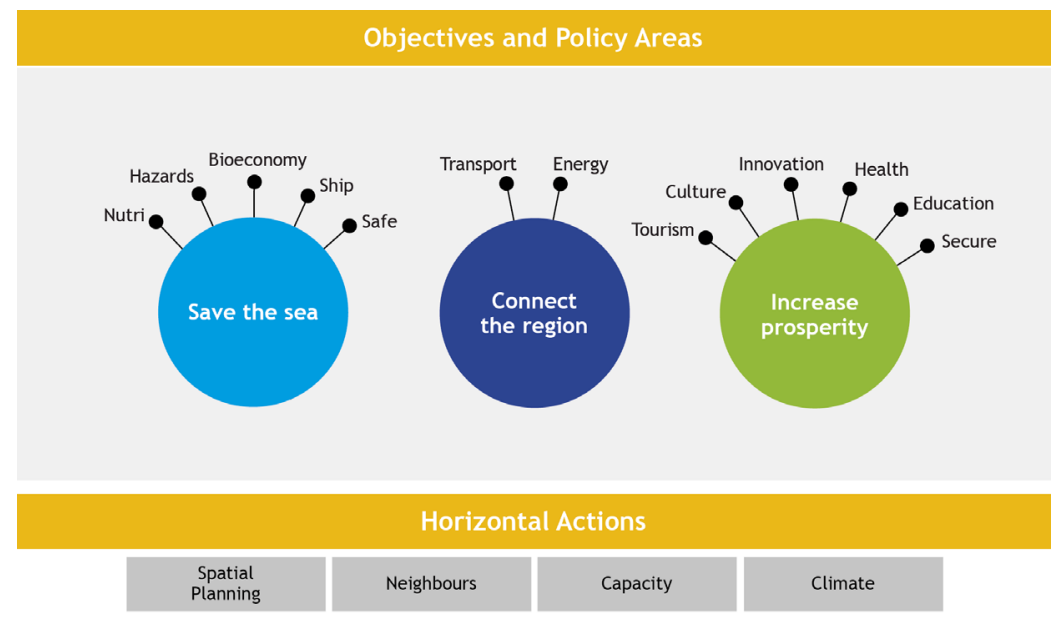

Figure 3. Architecture of the EUSBSR

Source: retrieved May 19, 2019 from https://balticsea-region.eu/about/implementation.

which is to say no new EU budget, no new EU institutions and no new EU regulations. Instead of creation new budgetary lines, the EUSBSR, and all macro-regional strategies, rely on alignment of existing funding sources in the macro-region. The overall implementation scheme is of a networking character and comprises voluntary actions of member states and pan-Baltic organisations, in terms of their taking care of PA/HA or national coordination (Fig. 4).

This work is supported by the Baltic INTERREG Program, which offers a specific priority for supporting institutional efforts of the EUSBSR (in form of support projects) and funding for the Flagships that must anyway meet criteria of the INTERREG funding. The European Commission is a regular publisher of reports on the implementation of the EUSBSR. Strategic guiding of the EUBSR is in turn secured through:

- a High-Level Group that gives advice to the European Commission on the EUSBSR and its implementation, and offers opinion on the updating and changing of the EUSBSR and its Action Plan.

- Annual Fora ${ }^{7}$ that bring together all relevant stakeholders to discuss the past and future of the EU BSR, and to review and analyse progress in implementing the strategy and present related recommendations as necessary (Zaucha, 2010).

As implementation mechanisms of the EUSBSR are described in detail in the document: 'Roles and responsibilities of the implementing stakeholders of the EUSBSR and a flagship project concept' (INTERACT, 2013), they are not presented in detail here.

In its documents, the EUSBSR reveals the main motives behind its establishment. These are listed under the headings of advantages that the BSR can gain out of the EUSBSR (Tillväxtverket, 2016). They are exemplary in nature, but illustrate the main expectations towards the EUSBSR:

1. Smarter problem-solving that means better opportunities for solving common problems that require fforts from all involved (e.g. environmental problems in the Baltic, poorly functioning transport routes, or the need for energy supplies).

2. Better approaches and methods, i.e. access to more approaches and methods for working with e.g. skills supply and sustainability issues.

\footnotetext{
${ }^{7}$ The first Annual Forum of the EUSBSR took place in Tallinn in October 2010 and the tenth will be held in Gdańsk in June 2019.
} 
3. Improved cooperation on environmental issues, i.e. on how to prevent floods and other matters related to adapting to climate change.

4. Larger market, i.e. access to a larger market for commercial products and services, and greater scope for economies of scale and scope.

5. Enhanced skills and larger networks, meaning also more contacts for making businesses and a stronger position on the global market.

6. Safety and security, i.e. joint actions in the field of crime prevention and crisis management.

7. Increased resources, mainly networking, ease with which new projects can be conducted, and access to a joint pool of know-how and experience.

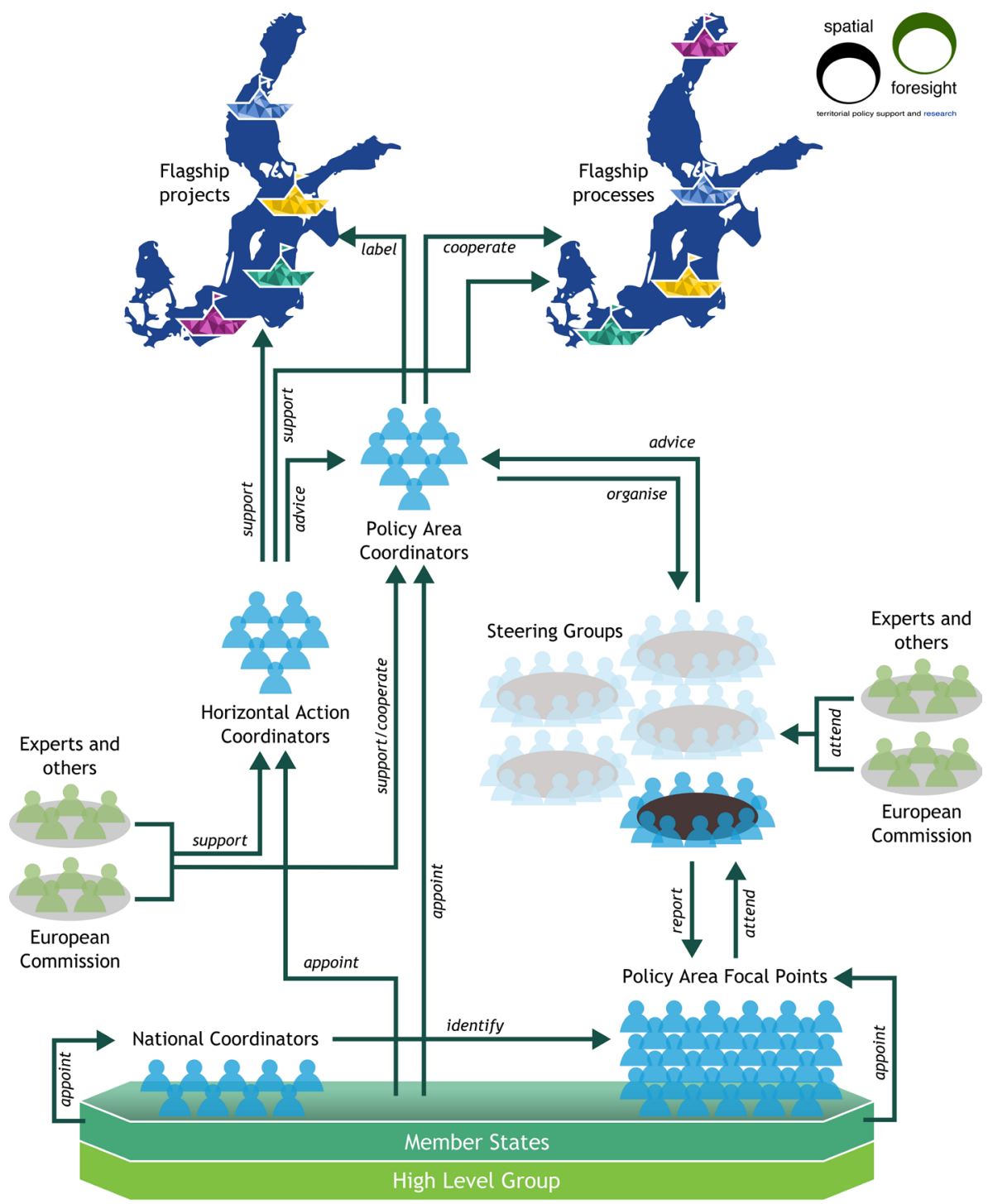

Figure 4. Implementation of the EUSBSR

Source: Toptsidou and Böhme (2018, p. 22) 
All those advantages correspond nicely with the theoretical framework provided in the previous section. They can be interpreted easily (Table 1), in the form of externalities (including economies of scope and scale), public goods and coverage of transaction costs. This gives evidence of their being a sound basis for the EUSBSR that is definitely more than just new EU bluster or a buzzword.

Table 1. Theoretical concepts underpinning advantages of the EUSBSR

\begin{tabular}{|l|c|c|c|c|}
\hline \multicolumn{1}{|c|}{ Advantage } & Externalities & $\begin{array}{c}\text { Public goods, club } \\
\text { goods, common- } \\
\text { pool resources }\end{array}$ & $\begin{array}{c}\text { Covering } \\
\text { transaction costs }\end{array}$ & $\begin{array}{c}\text { Economies of scope } \\
\text { and scale }\end{array}$ \\
\hline Smarter problem-solving & ++ & + & & \\
\hline $\begin{array}{l}\text { Better approaches } \\
\text { and methods }\end{array}$ & ++ & ++ & + & ++ \\
\hline $\begin{array}{l}\text { Improved cooperation } \\
\text { on environmental issues }\end{array}$ & + & + & + & + \\
\hline Larger market & + & & & + \\
\hline $\begin{array}{l}\text { Enhanced skills and larger } \\
\text { networks }\end{array}$ & ++ & ++ & + & + \\
\hline Safety and security & + & & & + \\
\hline $\begin{array}{l}\text { Increased resources } \\
\text { (networking) }\end{array}$ & + & + & & + \\
\hline
\end{tabular}

Source: authors' own elaboration.

Similar analysis can be conducted at the level of PA or HA, but the results would be similar. For instance the Horizontal Action on Spatial Planning contributes to externalities and covers some transaction costs. The Policy Areas Nutri and Hazards are related to externalities and a common-pool resource, Secure and Culture - to public goods, and Innovation - to externalities and the covering of transaction costs. However, as such analysis is not crucial for its purposes, this study confines itself to the advantages analysis. From it, one can conclude that the dominating motives for pursuing and maintaining the EUSBSR relate to externalities, whereas more-subtle interventions concerned with the covering of high initial costs of some business activities are less frequent. According to recent assessments, all EUSBSR objectives 'demonstrate in various forms that the Macroregional approach provides concrete added value' (CEC, 2018, p. 62).

\section{The EU Strategy for the Baltic Sea Region from a Polish Presidency of the Council of the Baltic Sea States national and research perspective}

In this chapter, Polish priorities as regards BSR integration are analysed, and related to the EUSBSR. The documents of the Polish Presidency of the Council of the Baltic Sea States (CBSS) ${ }^{8}$ serve as the main source of information. Poland is active in seeking collaboration with BSR regional organisations and networks. The country strives to improve cooperation by seeking synergies and ensuring cohesion with the BSR stakeholders, developing cross-border connectivity and BSR

\footnotetext{
${ }^{8}$ CBSS as an intergovernmental organisation is also a forum for multilateral intergovernmental cooperation, and one of the key actors at the macro-regional scale with significant strength available for use (CBSS, 2018, 2020). The CBSS was founded by the BSR governments and the European Commission in 1992. Key priority areas of the CBSS co-operation (agreed in 2014) are following: (1) regional identity, (2) sustainable and prosperous region, and (3) safe and secure region (CBSS, 2014).
} 
dialogue and communication. Polish authorities have been taking an active part in various BSR cooperation networks. In 2015, for the third time, Poland took on the annual CBSS Presidency. During its chairmanship, Poland tried to enhance sustainability and resilience of the BSR.

In its preparatory documents, the Polish Government declared that it considered the CBSS Presidency: (1) one of the priorities of Polish foreign policy, and (2) one of the two pillars of Polish regional policy. Poland further saw the Polish CBSS Presidency as a significant impulse for a strengthening of Polish involvement in BSR integration, since the newly-adopted EUSBSR Action Plan was considered a good vehicle by which to raise the effectiveness of cooperation among BSR stakeholders, as well as cohesion among existing regional cooperation networks (CBSS, 2016). The main motto of the Polish CBSS Presidency 2015-2016 was 'synergy in diversity'.

The Polish CBSS Presidency substantiated three CBSS priority areas by concentrating its efforts on sustainable development (a sustainable and prosperous region), creativity (regional identity) and security (a safe and secure region). In the field of sustainable development, the Polish CBSS Presidency focused on continuing with the activities related to adaptation to climate change, in order to limit the associated economic and social risks. As a result of the Presidency activities, the Declaration entitled 'Baltic 2030. Renewing the Commitment to Sustainable Development in the Baltic Sea Region' was adopted, this being a regional response to the implementation of the United Nations Sustainable Development Goals (UN ASG, 2015; UN SDG, 2015). A further important element of the Polish Presidency's agenda was a strengthening of the integrated approach to maritime affairs, including a sustainable transport system in the BSR.

Where the concept for Polish CBSS Presidency priorities was concerned, creativity was understood quite broadly as part of culture, i.e. as a tool operating in support of socioeconomic development in the BSR (creativity + cooperation = development). In this sense, culture has become a part of the CBSS regional-identity priority. The aim was to promote BSR culture through transnational interdisciplinary projects. The emphasis was on increasing the efficiency of existing and emerging networks of key cultural organisations and institutions, as well as increasing awareness of the decision-making process in regard to the importance of cultural projects and the role of culture in the BSR's socioeconomic development, with particular emphasis on creative sectors.

During the Polish CBSS Presidency measures were taken to enhance civil protection in the BSR in line with the third CBSS priority area. Actions sought to strengthen the potential for a regional response and interoperability of services, through the effective use of civil protection modules in the region, and closer cooperation to combat the effects of disasters.

Numerous meetings of pan-Baltic networks and organisations were hosted by Poland during its CBSS Presidency. Among those worth mentioning here: the Meeting of the Deputy Foreign Ministers in Warsaw (Warsaw Declaration: 'Regional Responses to Global Challenges'); $9^{\text {th }}$ Conference of the Ministers of Culture of the Baltic Sea States in Gdańsk, $1^{\text {st }}$ Meeting of the Ministers of Science in Kraków (Chair's Conclusions: 'Baltic Science: Renewing the Commitment to Science/Research Joint Actions in the Baltic Sea Region'), Baltic Sea Cultural Gathering in Gdańsk ('Gdańsk-Manifesto"), Warsaw Seminar on the future of the Baltic Sea cooperation, $8^{\text {th }}$ Baltic Sea Tourism Forum in Gdańsk and Malbork, $14^{\text {th }}$ Meeting of the Directors General for Civil Protection in Gdańsk, $5^{\text {th }}$ Roundtable of the Baltic Sea Region Climate Change Dialogue Platform, Baltic Sea Labour Forum in Gdańsk (Statement 'BSLFmobINIT: New Perspectives through Vocational Mobility') and some others (CBSS 2016).

In summing up this part of analysis, we can suggest that Poland tried to contribute to two CBSS-led horizontal actions of the EUSBSR in a very pragmatic way, through contingency planning (civil protection), enhancing BSR culture and co-operation, and all these within the framework 
of the sustainable development concept. Despite having capital located far from the Baltic coast, Poland attached serious priority status to BSR development and integration, at least during the time of its CBSS Presidency. The country has pursued a quite wide, all-embracing and broad array of activities in line with the needs of BSR countries and stripped itself of national egoism or a narrow rent-seeking attitude.

The research query among young scholars at the University of Gdańsk (Faculty of Economics) has underlined the importance of two BSR cooperation topics from an academic perspective. These are transborder SME cooperation, academia and SME cooperation in the BSR and cooperation over tourism in the BSR, in the context of both sustainable and active tourism. Key arguments of young scholars justifying their choice are provided below.

An increase in prosperity, as one of the objectives and policy areas of the EUSBSR, is focused, i.e. on education and innovation. More-efficient cross-border collaboration between academia and SMEs seems a very important issue and one that has a key role to play in successful continued development (ScanBalt Report, 2013). There is a need for further and deeper SME - academia interaction and collaboration, with a view to overcoming regional gaps and bottlenecks. The 'Smart Growth: Bridging Academia and SMEs in the Baltic Sea Region' report underlines the necessity of innovative SME integration into clusters, implementation of best practices, establishment of pilot activities, service and support tools and self-assessment programs. The BSR is one of three most innovative and efficient regions (Hogeforster, 2011). SMEs are considered the backbone of the economy. The promotion of SMEs in the BSR and development support should be continued with, in order to ensure a strengthening of the competitive position on the global market ( Hogeforster, 2011).

Another issue under Strategy consideration with a view to prosperity being increased is tourism as a part of the sustainable and responsible development of the BSR. Regarding the 'State of the Tourism Industry in the Baltic Sea Region - 2018 Edition', the Baltic Sea tourism industry is rising, and is exerting a strong influence on the economy of the region, given that over 638000 people are employed directly in tourism, while the contributions to GDP are at levels between 1.9 and $4.6 \%$. The Baltic Sea Tourism Center (BSTC) was established to represent the common interests of business, academia and politics, to develop and implement joint long-term tourism marketing strategies. BSTC works for a wider awareness of the BSR, and to promote its image as a worthwhile travel destination (KEEP).

\section{The ups and downs of the EU Strategy for the Baltic Sea Region}

The BSR collaboration seems deserving of the highest level of appreciation. According to Ketels et al. $(2017$, p. 7) 'Collaboration across the Baltic Sea Region is a tremendous success story (...) BSR cooperation has achieved many of its objectives, particularly with regards to removing the boundaries that has kept the Region apart before 1990'. The same authors underline that this feeling of success is also the perception of leading politicians across the macro-region (Ketels et al., 2017). However, a question remains regarding the real contribution of the EUSBSR to those BSR successes.

Positive evaluation of EUSBSR outcomes is prevalent, and the European Commission seems satisfied with the results achieved. In 2011, it praised the Strategy for addressing key challenges and untapped potential, providing an integrated framework for improvement of environmental conditions, tackling transport bottlenecks and energy interconnections, and facilitating

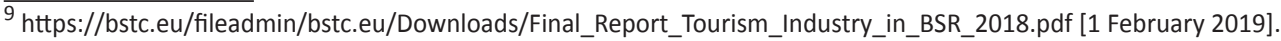


the development of markets across borders, as well as common networks for research, innovation and enterprises (CEC, 2011b). In 2016, the Commission underlined the following important results that have been obtained:

- creation of new solid, and better, utilisation of the existing networks across all political levels and among actors from different sectors,

- new projects and processes of macro-regional relevance, as well as an addition of momentum to existing ones,

- a strengthening of ties and a deepening a dialogue between different actors at all levels of governance,

- enhancement of cross-strategy (with other macro-regional strategies) and cross-cutting cooperation,

- increased interest in, and more attention to, territorial cooperation and cohesion, and an interest in transboundary and transnational cooperation within the BSR,

- strengthened coordination and cooperation between and within different institutions at different levels (including relevant Commission services), as well as between different stakeholders and authorities within countries,

- better and more efficient use of existing funding tools.

A majority of these outcomes relate to exchange of experience and facilitated acquaintanceship among BSR stakeholders. Recently it has been spelled out more explicitly than hitherto that a key added value of the EUSBSR is 'that the Strategy brings together new actors across sectors, countries and levels' (CEC, 2018, p. 70). However, those achievements are less related to transaction costs of the business sector being covered, even if networking can be seen as a precondition for that to be done. Also public goods or common-pool resources are not mentioned explicitly in the aforesaid list. It seems that, after ten years, the EUSBSR is still at an initial stage of the delivery of public goods and securing of transaction-cost coverage. This can be interpreted as a still-pending challenge, with a view to the behaviour and decisions of private business being affected by way of EUSBSR actions.

The EUSBSR has also raised an intensive academic debate on macro-regional collaboration within the EU. Numerous scientific publications have been elaborated to contribute to this discourse. A majority of these were related to the EUSBSR or its comparison with other EU strategies (Bengtsson, 2009; Dubois, Hedin, Schmitt \& Sterling, 2009; Dühr, 2011; Gänzle, 2017, 2018; Gänzle \& Kern, 2016; Gänzle \& Mirtl, 2017; Gänzle \& Wulf, 2014; Schymik, 2011; Schymik \& Krumrey, 2009; Zaucha, 2010, 2013; Zaucha \& Török, 2011). Such immense inspiration of the social sciences with new a research topic should definitely be treated as a tangible achievement of the EUSBSR.

However, there are also severe critical opinions concerning some specific features of the EUSBSR. Some of these were articulated years ago but still seem valid. Worth mentioning are:

- the all-encompassing and thus excessively broad scope and approach (Bengtsson, 2012; Tillväxtverket, 2016, p. 35; Toptsidou \& Böhme, 2018) resulting in a 'Christmas tree' type of strategy (Ketels 2009) and lack of hierarchy of priorities (Tillväxtverket, 2016, p. 35),

- a perceived limited influence on EU territorial cohesion or spatial development policy (CEC, 2018),

- flagship projects that are too small to achieve policy change - even though they suggest desired change in macro-regional development, they cannot in and of themselves trigger such change (Toptsidou \& Böhme, 2018),

- limited private-sector participation (at least in strategic guiding work) and concomitant over-commitment of the public sector (Held, 2011),

- an absence of certain efforts in the direction of standardisation, i.e. one central benchmark deciding on the urgency of actions (Ketels, 2009), 
- an ad hoc approach with regard to the collection and maintenance of project results (CEC, 2018), as well as insufficient harmonisation of the process by which flagship status across PA is obtained (Toptsidou \& Böhme, 2018),

- insufficient 'ownership' of the EUSBSR, given that some players seem to have little interest or involvement in the macro-regional processes (Toptsidou \& Böhme, 2018) and resultantly problems with leadership (Tillväxtverket, 2016, p. 35),

- complicated architecture (and relations between actors) mainly due to the multi-layer coordination, and the international co-operation required at each co-operation level (Held, 2011), with these creating confusion as regards what in reality drives policy change (Toptsidou \& Böhme, 2018),

- a lack of long-term, flexible financing in support of work in the policy areas (CEC, 2018), despite various efforts to align financing sources (Haarich, Hermannek \& Holstein, 2015).

In addition, Ketels et al. (2017) have pointed to a missed opportunity to strengthen the BSR voice at the EU level. This can be interpreted as a lack of strategic leadership, and focus on operational tasks under existing collaboration structures including the EUSBSR. This would seem to be a substantial weakness in the light of the need, presented in the introductory part of this paper, for a strategic approach as a determinant constituting the BSR.

Ten years ago, Ketels (2009) raised the very relevant concern that a macro-regional approach would not solve all problems automatically, though it might indeed create opportunities to that end. However, according to one of the key EUSBSR Polish stakeholders in Poland - R. Matczak, as Director of the Department of Regional and Spatial Development at the Office of the Marshal of Pomorskie Region - the EUSBSR would need to be seen as a missed or unused opportunity from this ten-year perspective $^{10}$.

Furthermore, a key politician from Pomorskie region ${ }^{11}$ (T. Aziewicz - Parliament Member), when asked about the EUSBSR, first praised the Strategy as offering added value beyond the BSR, and then also underlined its orientation as an expert and executive authority. In his opinion, 'the Strategy, de facto, does not exist in the collective consciousness, and this is true of both the regional and national dimensions. In the discussions taking place in the Polish Parliament, it is present only occasionally (...). The fact that the document does not evoke more emotions is not its strong point, rather it is a result of participants in the debate being limited to a rather narrow group.'

That would suggest that, while EUSBSR results are obvious to those engaged in its implementation, and nicely compiled in assessments reports, they are not visible to the general public, or even to local or regional decision makers. The actual commitment to the EUSBSR is limited at both the national and the sub-national levels. According to Matczak, even proactive attitudes of the Polish National Contact Point at the Ministry of Foreign Affairs and a successful CBSS Presidency have proved insufficient in seeking to change this situation. Important barriers for the Pomorskie region that could be alleviated through BSR cooperation remained intact.

Furthermore, where certain key aforementioned problems requiring public intervention are concerned, it is easy to note that the East-West innovation divide has not been abolished, while the Single Market for providers of services has not been strengthened. These are only examples. Surprisingly, Pomorskie region lacks systematic assessments of the impact of the EUSBSR on its own development. It would thus seem that great enthusiasm for the EUSBSR is coupled with a passivity syndrome or limited trust in the ability of the Strategy to actually influence development.

\footnotetext{
${ }_{10}$ Personal communication dated January 6, 2019.

11 Interview conducted on February 10, 2019 (full text provided in Annex).
} 
Bearing in mind the analytical framework applied in this paper it is possible to conclude that the EUSBSR has not managed to cover the transaction costs that stand behind the East-West innovation divide, despite fast growth in northern Poland. Thus a critical mass for innovation spillovers outside the Scandinavian core has not been achieved. There has also been insufficient political commitment where the installation of a Single Market for services is concerned. As a consequence, there has been limited achievement of the advantage accruing from access to a larger services market (see Table 1).

All of this means that Polish providers of services cannot feel positive effects for their businesses attributable to the EUSBSR. It would thus seem that a key weakness of the EUSBSR lies in its limited impact on the behaviour or decisions of the private sector and perhaps also the general public. An expectation formulated by Böhme et al. (2016) - to the effect that the EUSBSR can bring the critical mass needed to ensure economic viability - has not been fulfilled in practice. In 2018, one of the authors of this paper interviewed CEOs of large Polish enterprises on the matters of BSR cooperation. They had a great deal of sympathy for the topic, but their actual knowledge of BSR cooperation and their own possible gains from it were limited. A summary of this part of the analysis would suggest that the logic and substance of the EUSBSR remains sound, but its implementation deserves another thought.

\section{The EU Strategy for the Baltic Sea Region beyond 2020}

Two documents have been elaborated, and debated widely, in order to pave the way for the EUSBSR's future. The first entitled 'Looking towards 2030: Preparing the Baltic Sea Region for the future' (Böhme et al. 2016) framed the discussion at the EUSBSR Annual Forum in 2016. Böhme et al. (2016) provides some reflections on what the future might bring for the BSR, and how to achieve EUSBSR objectives in a rapidly-changing context. The second 'EUSBSR after 2020: governance remastered?' (Toptsidou \& Böhme, 2018) discusses how the Strategy should evolve in a changing environment and was presented to the Annual Forum in 2018. The first is more in the nature of foresight, while the second is more process-oriented.

The first report (Böhme et al., 2016) identified 35 trends, all of which have implications for the BSR and the EUSBSR. Those trends have been grouped into four more major components, i.e.:

- changing demographic pressures and flows,

- renewing industries and innovation,

- deepening the environmental conversation,

- changing democratic decision-making and governance.

The main conclusion arising from analysis is validity of EUSBSR objectives and a lack of any need for new macro-regional objectives to address these trends. The report highlights areas in which cooperation must or should be intensified in the light of trends.

A crucial question that follows is which issues need to be solved at macro-regional level and which are better dealt with at lower or higher governance levels. The Figure 5 provides a quick overview of considerations for identifying issues requiring increased macro-regional cooperation.

In the first category, a majority of suggestions relate to negative externalities (environmental and climate challenges of clean and safe shipping) and public goods (civil protection, cooperation culture). An exception is blue growth, which can be seen in terms of transaction costs being covered with a view to appropriate conditions for its occurrence being put in place. These are topics, with sort of imperative need for cooperation as joint solutions or macro-regional structures 
are required to accomplish the task. In these cases, responses by individual countries, regions or municipalities will not solve the issue.

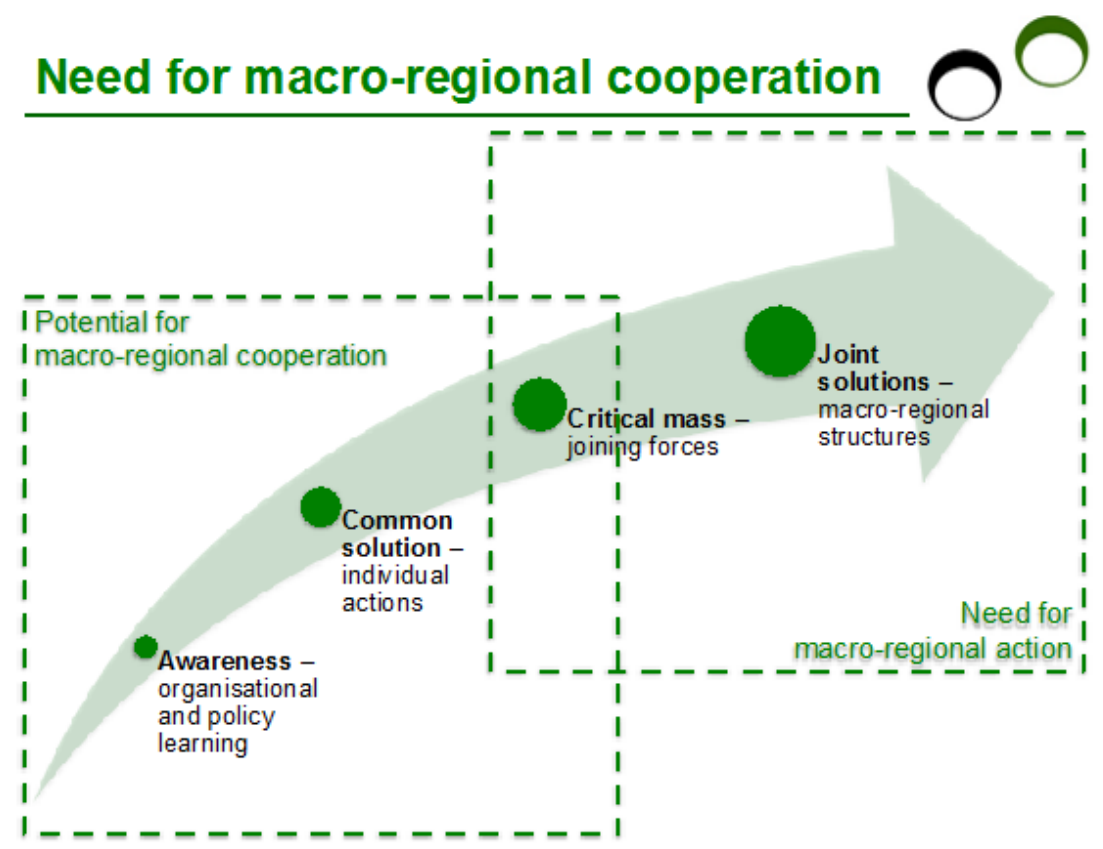

Figure 5. Need for macroregional co-operation and action Source: Böhme et al. (2016, p. 32).

Adding to the report, one more structural feature has surfaced which might fit this first category and require macro-regional action: territorial fragmentation (Böhme \& Martin, 2019). Increasingly Europe's territorially diversity and disparities is fuelling developments where groups of society and territories feel detached from European, transnational and national developments. The question is in how far do people perceive that they and the places they live in are left behind (Dijkstra, Poelman \& Rodríguez-Pose, 2018), politically abandoned (Hillje, 2018) or do not matter (Rodríguez-Pose, 2018), as different cities and regions in Europe face different everyday realities and their inhabitants see different future perspectives; not all of them hopeful ones (Böhme, Lüer \& Toptsidou, 2019). The EUSBSR could be essential to ensure that people in all parts of enjoy hopeful future perspectives.

In the second category there are two more transaction-cost-type interventions related to critical mass for digitisation and preparedness for new technologies; as well as one related to a public good enhancing growth directly (i.e. connectivity at macro-regional level). These are topics where cooperation can contribute to organisational and policy learning and where different stakeholders face similar challenges or opportunities to which common solutions can improve individual responses. In addition, macro-regional cooperation can also help achieve critical mass for an action or economic viability. In this case there is a need to cooperate.

The report also contains a plea for more coherent action of a cross-cutting nature in relation to: - global competitiveness in the context of the fourth Industrial Revolution,

- changing economic perspectives globally,

- the mitigation of demographic pressures in the BSR. 
The second report (Toptsidou \& Böhme, 2018) evaluates the validity of trends identified in 2016 and concludes that these are valid, but that some deserve even more attention than they receive. The matters in question are tension between Russia and the EU, demographic change, migratory pressure, sharing and the circular economy, blue-green growth and clean technologies, the fourth Industrial Revolution and climate change. These are all associated with new insights for the BSR's future development.

However, the key added value of the report lies in its recapitulation and substantiation of the ongoing discussion on the future of the EUSBSR. The main points are: simplification/ streamlining in the face of a subject focus that is too wide, as well as complex governance structure; coordination of priority actions though Thematic Partnerships similar to those established under the EU Urban Agenda; the development of Macro-regional Integrated Territorial Investments; and the utilisation of Article 70 of the Common Provisions Regulation as regards European structural and investment funds to bring about better alignment of funding (art. 70 opens doors for the acceptance of operations implemented outside the Programme area under national and other operational programmes). More far-reaching proposals described below in detail (Fig. 6) relate to:

- a shift from macro-regional flagship projects to Macro-regional processes. The latter might be implemented through interlinked activities, such as meetings, platforms, etc. and operations such as funded projects. This should ensure a broader policy impact.

- installation of continuous monitoring of the EUSBSR and development of the BSR, with a view to ex-post evaluation of flagship results being assured,

- installation of mechanisms that improve stakeholder commitment to results and the visibility of EUSBSR outputs at a high political level (e.g. through the idea of an EUSBSR Ambassadors Club).

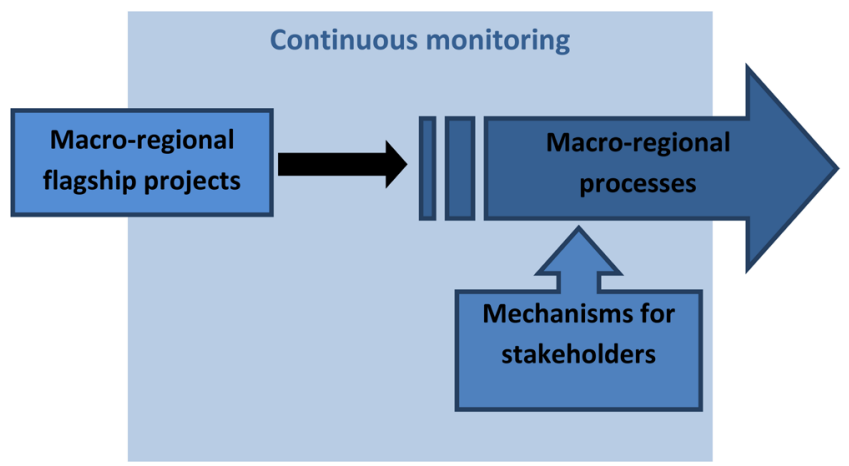

Figure 6. Improvements in implementation of the EUSBSR as proposed by Toptsidou \& Böhme (2018) Source: L. Neumann elaboration.

The other suggestions concern simplification and communication: directing EUSBSR objectives and PA more towards future trends and challenges, integration of objectives and PA to take account of global priorities (such as the UN Sustainable Development Goals, the Paris Agreement, as well as the UN Urban Agenda), closer synergies between PA and HA and other Baltic Sea actors, developing a lingua franca macro-regionalis. 
As this part of the discussion concludes, it should be noted that the discourse on the future of the EUSBSR is very intensive, and based on actual evidence collected in the course of implementation work. However, it is also clear that the progress does not match expectations. In the light of that, what are summarised below are the suggestions of Polish researchers regarded necessary changes in the EUSBSR, as these were formulated back in 2013. However, they do also correspond with recent ideas. This in itself might raise a question regarding the political commitment within the EUSBSR implementation structure (see Fig. 3) to bring about necessary change. After Zaucha (2013), the said Polish proposals were:

- to introduce an EUSBSR requirement directly in the Development and Investment Partnership Contracts concluded with BSR member states (in line with suggestions that political commitment be increased and funding aligned);

- to implement the EUSBSR in a cross-cutting manner, and monitor its effects (in line with the need for a broader policy impact to be exerted);

- to make use of tools of conditionality, i.e. a condition that EU funding release be related in some cases to the existence of relevant pan-Baltic agreements e.g. on the BSR as a phosphorus-free region (in line with suggestions regarding political commitment and the alignment of funding);

- to bring business into Strategy implementation (in line with the need for a broader policy impact and ownership of results).

To be added to this today is the plea for the EUSBSR to integrate the work of the European Commission as a whole, and not merely the Directorate-General for Regional and Urban Policy as such. T. Aziewicz is also of the opinion that 'Strengthening awareness of the Strategy is worth considering, and it requires taking additional public relations efforts and incorporating the Strategy into political discussions, also with the involvement of national parliamentarians who should act as a natural transmission belt between the executive and citizens. ${ }^{12}$

It would thus seem that EUSBSR development beyond 2020 should operate in line with the following conclusions and assumptions:

1. The EUSBSR is a valuable policy tool contributing to the creation of relational and social capital for the BSR, ensuring that all places have hopeful future perspectives (Böhme et al., 2019) and areas of discontent (Dijkstra et al., 2018) are addressed. This task should be continued with, even at the expense of overall efficiency, and even where more spectacular outcomes of the EUSBSR are lacking. However, in such a case the existing transnational funding is sufficient.

2. If the EUSBSR seeks to reach a new stage of development, its key shortcomings need to be addressed. These are, in particular, a limited influence on the behaviour and decisions of private actors, a failure to ensure a strategic approach for BSR development and limited impact on policies. The removal of these shortcoming would change the image of the EUSBSR from being a kind of 'talking shop' through to being a club that is more action-oriented.

3. Some promising changes relate to cross-cutting work, i.e. the uptake of large political projects understandable and important to BSR societies, authorities and businesses. An example can be a concept of the BSR as a macro-region pioneering implementation of the circular economy concept. This has been proposed by Toptsidou and Böhme (2018) and raised in status by Polish organisers to key motive at the tenth EUSBSR Annual Forum in Gdańsk. Another idea might be the BSR Single Services Market or an EU innovation hub (as described above). Such projects are of key importance to the visibility of the EUSBSR, and to stakeholder mobilisation around important tasks. However, it needs to be recalled that such large projects should not take the place of the existing networking and discussions that are of great value to the future of the BSR (see point 1).

12 Interview conducted on February 10, 2019 (full text provided in the Annex). 
4. Large projects should be based on a high-level political commitment anchored if possible in international agreements that bring together both national and international funding and resources supported by national parliaments.

5. The EUSBSR should be mainstreamed into policy work of the BSR governments and the entire European Commission:

- The Strategy should influence key policy documents at EU and national level.

- It should serve as a coordination vehicle for work of all Directorates-General with regard to the BSR. Its influence should not be confined to the work of the Directorate-General for Regional and Urban Policy.

- It should act as a vehicle for conscious co-operation between and harmonisation of the use of different funding sources. Transnational programmes should cease to act as an actual main source of financing of EUSBSR activities. The regional, national and sectoral funds have to link directly with the EUSBSR.

- There is a need for regular EUSBSR impact assessments to see how the EUSBSR influences various policies.

6. Current leaders of BSR implementation should learn to locate low-hanging fruits in terms of covering transaction costs of activity of private businesses crucial to the competitive position of the BSR. For that reason, expert- or politician-moderated dialogue should be installed in the private sector (in order that rent-seeking behaviour can be avoided).

7. Macro-regional solidarity is a sine qua non condition of EUSBSR success in the future. The Strategy will not deliver policy results in the absence of such solidarity. Without accepting the redistribution of costs and benefits of BSR development among BSR countries, the Strategy will not exceed the pilot and discussion phase remaining on the outskirts of real policies.

\section{References}

Bengtsson, R. (2009). An EU Strategy for the Baltic Sea Region: good intentions meet complex challenges. European Policy Analysis, 9, Stockholm: SIEPS.

Bengtsson, R. (2012). The EU Strategy for the Baltic Sea region in 2012 - implementation challenges. Baltic Rim Economies Quarterly Review, 1, 27.

Böhme, K., \& Martin, D. (2019). Territorial Fragmentation: A Major European Challenge. Territorial Thinkers' Briefing, 5. Luxembourg: Territorial Thinkers. Retrieved from https://territorialthinkers.eu/ files/territorial_theme/Downloads/TT\%20brief\%20V-190430Final.pdf

Böhme, K., Lüer, C., \& Toptsidou, M. (2019). Towards a European Geography of Future Perspectives: A Story of Urban Concentration. In E. Medeiros (Ed.), Territorial Cohesion: The Urban Dimension (pp. 173-191). Cham: Springer International Publishing. https://doi.org/10.1007/978-3-030-033866_9

Böhme, K., Toptsidou, M., Holstein, F., \& Martin, D. (2018). Territorial Cooperation for the future of Europe, ESPON contribution to the debate on Cohesion Policy post 2020. European Territorial Review, Luxembourg: ESPON EGTC.

Böhme, K., Zillmer, S., Hans, S., Antikainen, J., \& Pyykkonen, S. (2016). Looking towards 2030: Preparing the Baltic Sea Region for the future. Luxembourg: Spatial Foresight.

Brodzicki, T., \& Umiński, S. (2017). A gravity panel data analysis of foreign trade by regions: the role of metropolises and history. Regional Studies, 52(2), 261-273. https://doi.org/10.1080/00343404. 2017.1296123 
Carlsen, P., Danielson, A., Gretskiy, I., Łada, A., \& Puglierin, J. (2018). Flexible Europe - What does it mean for the Baltic Sea Region? Copenhagen/Riga: Baltic Development Forum and Konrad Adenauer Stiftung.

CBSS (2014). Decision by the Council of the Baltic Sea States on a review of the CBSS long priorities, adopted through silent procedure on 20 June 2014. Retrieved from http://www.cbss.org/cbss-long-term-priorities/

CBSS (2016). Council of the Baltic Sea States, Annual Report for the Polish Presidency 2015-2016. Retrieved from http://www.cbss.org/wp-content/uploads/2016/10/annual_polish_report_online4.pdf

CBSS (2018). CBSS Information and Communication Strategy 2018. Retrieved from http://www.cbss.org/ council/coordination-2/\#1530799638113-6e1fb7a0-aba

CBSS (2020). CBSS Vision Group Report: Vision for the Baltic Sea Region beyond 2020. Retrieved from http://www.cbss.org/council/coordination-2/\#1530799638113-6e1fb7a0-aba7

CEC (2009, June 10). Communication from the Commission to the European Parliament, the Council, the European Economic and Social Committee and the Committee of the Regions concerning the European Union Strategy for the Baltic Sea Region. COM(2009) 248 Final, Brussels.

CEC (2011a). European Territorial Cooperation Building Bridges between People. Luxembourg: Publications Office of the European Union.

CEC (2011b, June 22). Report from the Commission to the European Parliament, the Council, the European Economic and Social Committee and the Committee of the Regions on the implementation of the EU Strategy for the Baltic Sea Region (EUSBSR). COM (2011) 381 Final. Brussels.

CEC (2014, July 23). Directive 2014/89/EU of the European Parliament and of the Council of 23 July 2014 establishing a framework for maritime spatial planning. O.J. EU, L 257/135.

CEC (2015). Territorial Cooperation in Europe. A Historical perspective. Luxembourg: Publications Office of the European Union.

CEC (2016). Commission staff working document accompanying the document "Report from the Commission to the European Parliament, the Council, the European Economic and Social Committee and the Committee of the Regions on the implementation of EU macro-regional strategies'. SWD(2016) 443 Final, Brussels.

CEC (2017). Commission staff working document European Union Strategy for the Baltic Sea Region Action Plan. SWD(2017) 118 Final, Brussels.

CEC (2018). Study on Macroregional Strategies and their Links with Cohesion Policy. Luxembourg: Publications Office of the European Union.

Deike, P. (2000). Center-Periphery Dynamics in the New Europe and Their Impact on Transport Infrastructure Planning in the Baltic Sea Region. Department of Urban Planning and Policy Development Rutgers University.

Dijkstra, L., Poelman, H., \& Rodríguez-Pose, A. (2018). The Geography of EU Discontent. Working Papers, 12/2018, Luxembourg: Publications Office of the European Union. Retrieved from https://ec.europa. eu/regional_policy/sources/docgener/work/2018_02_geog_discontent.pdf

Dubois, A., Hedin, S., Schmitt, P., \& Sterling, J. (2009). EU Macro-regions and macro-regional strategies - a scoping study. Nordregio Electronic Working Paper, 4, Stockholm: Nordregio.

Dühr, S. (2011). Baltic Sea, Danube and macro-regional strategies - a model for transnational cooperation in the EU? Notre Europe Study and Research, 86. Paris: Notre Europe.

Ehler, C., Zaucha, J., Gee, K. (2019). Maritime/Marine Spatial Planning at the interface of research and practice. In: J. Zaucha, \& K. Gee (Eds.), Maritime Spatial Planning, past, present, future (pp. 1-21). London, Cham: Palgrave. https://doi.org/10.1007/978-3-319-98696-8_1

ESPON (2007). Cross-Border Cooperation. Cross-Thematic Study of INTERREG and ESPON activities. LuXembourg: INTERACT \& ESPON.

ESPON (2012). KIT Knowledge, Innovation, Territory Applied Research. Final Report. Luxembourg: ESPON \& Politecnico di Milano.

EuroFutures (1994). Perspective for the Economic Development of the Baltic Region. Stockholm: EuroFutures.

Gänzle, S. (2017). EU governance, "Experimental Union', and Baltic Sea cooperation: The case of the European Union's Strategy for the Baltic Sea Region. Schuman Papers. Retrieved from http://www. schuman-seura.fi/wp-content/uploads/2017/10/Schuman_Paper_2-2017_WEB.pdf 
Gänzle, S. (2018). 'Experimental Union' and Baltic Sea cooperation: the case of the European Union's Strategy for the Baltic Sea Region (EUSBSR). Regional Studies, Regional Science, 5(1), 33-352. https:// doi.org/10.1080/21681376.2018.1532315

Gänzle, S., \& Kern, K. (2016). The European Union Strategy for the Baltic Sea Region. In S. Gänzle, \& K. Kern (Eds.), A 'Macro-regional' Europe in the Making. Theoretical Approaches and Empirical Evidence (pp. 123-144). Basingstoke: Palgrave Macmillan.

Gänzle, S., \& Mirtl, J. (2017). Experimentalist governance in a multi-level environment. The EU's Macroregional strategies for the Baltic Sea and Danube Regions. In J. Trondal (Ed.), The rise of common political order. Institutions, public administration and transnational space (pp. 154-175). Cheltenham and Northampton: Edward Elgar Publishing.

Gänzle, S., \& Wulf, J. J. (2014). Briefing note - The emerging core of the EU's Macro-regional governance architecture: mapping the roles, tasks and self-perceptions of Priority Area Coordinators and Horizontal Action Leaders in the EU Strategies for the Baltic Sea and the Danube Regions. ISL Working Paper, 1, Kristiansand: University of Agder.

Haarich, S., Hermannek, P., \& Holstein, F. (2015). Available funding sources for the implementation of the European Union Strategy for the Baltic Sea Region. Luxembourg: Spatial Foresight.

Held, J. (2011). Aspects of territorial cohesion in the EU Strategy for the Baltic Sea region. In J. Zaucha (Ed.), Territorial Cohesion - Baltic Sea region examples. Baltic contribution to the Revised Territorial Agenda of EU (pp. 22-25). Ecoregion Perspectives, Baltic 21 Series, 2. Gdańska: Baltic 21.

Hillje, J. (2018), Return to the politically abandoned. Conversations in right-wing populist strongholds in Germany and France. Berlin: Das Progressive Zentrum. Retrieved from https://www. progressives-zentrum.org/wp-content/uploads/2018/10/Return-to-the-politically-abandoned-Conversations-in-right-wing-populist-strongholds-in-Germany-and-France_Das-Progressive-Zentrum_ Johannes-Hillje.pdf

Hogeforster, M. (2011). Objectives and Strategies for the Development of Crafts and SMEs in the Baltic Sea Region. Retrieved February 1, 2019 from https://books.google.pl/books?id=4yknf90QE4C\&printsec$=$ frontcover $\& \mathrm{hl}=\mathrm{pl} \# \mathrm{v}=$ onepage $\& \mathrm{q} \& \mathrm{f}=\mathrm{false}$

INTERACT (2013). Roles and responsibilities of the implementing stakeholders of the EUSBSR and a flagship project concept. Retrieved January 1, 2019 from https://www.balticsea-region-strategy.eu/ action-plan?task=document.viewdoc\&id=2

Jacobsen, B. P. (Ed.) (2018). BSTC Baltic Sea Tourism Center. State of the Tourism Industry in the Baltic Sea Region - 2018 Edition. Stralsund, DE: Stralsund University of Applied Sciences. Retrieved January 31, 2019 from https://bstc.eu/fileadmin/bstc.eu/Downloads/Final_Report_Tourism_Industry_in_BSR_2018.pdf

Jetoo, S. (2018). Experimentalist Governance to Foster Cooperation in the Baltic Sea Region: A Focus on the Turku Process. Sustainability, 10, 2685. https://doi.org/10.3390/su10082685

Karlsson, M. (2004).Transnational Relations in the Baltic Sea Region. Södertörn Academic Studies 21, Huddinge: Södertörns högskola.

KEEP (n.d.). Keep. EU project database. Retrieved January 31, 2019 from http://www.keep.eu

Ketels, C. (2009). State of the region report 2009, Copenhagen/Helsinki: Baltic Development Forum in collaboration with the Nordic Council of Ministers and the Nordic Investment Bank.

Ketels, C., Pedersen, H. J., \& Olsson M. (2017). State of the Region Report. The Top of Europe - A Competitive Baltic Sea Region Ready for the Future? Copenhagen: Baltic Development Forum in collaboration with the Nordic Council of Ministers.

Kukk, M., Jervell, S., \& Joenniemi, P. (Eds.) (1992). The Baltic Sea Area - A region in the making. Oslo: The Baltic Institute.

McMaster, I., \& van der Zwet, A. (2016). Macro-regions and the European Union: the role of cohesion policy. In S. Gänzle, \& K. Kern (Eds.) A 'Macro-regional' Europe in the Making. Theoretical Approaches and Empirical Evidence (pp. 47-71). Basingstoke: Palgrave Macmillan.

Medeiros, E. (2018). Should EU cross-border cooperation programmes focus mainly on reducing border obstacles. Documents d'Analisi Geografica, 64(3), 467-491.

Mirwaldt, K., McMaster, I., \& Bachtler, J. (2011). The Concept of Macro-Regions: Practice and Prospects. European Policy Research Paper, 76. Glasgow: EPRC University of Strathclyde. 
Nazarczuk, J., Umiński, S. (2018). The impact of special economic zones on export behaviour: evidence from Polish firm-level data. Ekonomie a Management, 21(3), 4-22.

OECD (2016). The Ocean Economy in 2030. Paris: OECD Publishing.

Poland (2015). Priorytety polskiej prezydencji w Radzie Państw Morza Bałtyckiego. Retrieved January 26, 2019 from https://www.msz.gov.pl/pl/polityka_zagraniczna/baltyk/prezydencja/priorytety/

Rodríguez-Pose, A. (2018). The revenge of the places that don't matter (and what to do about it). Cambridge Journal of Regions, Economy and Society, 11(1), 189-209.

Samecki, P. (2009). Macro-regional strategies in the EU. A Discussion Paper presented by Commissioner Paweł Samecki in Stokholm on 18 September 2009. Retrieved December 25, 2018 from https:// ec.europa.eu/regional_policy/archive/cooperate/baltic/pdf/macroregional_strategies_2009.pdf

ScanBalt Report (2013). Smart Growth: Bridging Academia and SMEs in the Baltic Sea Region. Retrieved January 31, 2019 from http://scanbalt.org/wp-content/uploads/2016/04/Smart-Growth-BridgingAcademia-and-SMEs-in-the-Baltic-Sea-Region.pdf

Schultz-Zehden, A., Weig, B., \& Lukic, I. (2019). Maritime Spatial Planning and the EU's Blue Growth Policy: Past, present and future perspectives. In J. Zaucha, \& K. Gee (Eds.), Maritime Spatial Planning, past, present, future (pp 121-150). London, Cham, CH: Palgrave.

Schymik, C. (2011). Blueprint for a macro-region. EU Strategies for the Baltic Sea and Danube Regions. SWP Research Paper, Berlin: German Institute for International and Security Affairs.

Schymik, C. (2012). The Baltic Sea Region: Who cooperates with whom and why? In N. Bellini, \& U. Hilpert (Eds.), Europe's changing geography. The impact of inter-regional networks (pp. 67-80). London: Routledge.

Schymik, C., \& Krumrey, P. (2009). EU Strategy for the Baltic Sea region. Core Europe in the northern periphery? SWP Working Paper. Berlin: German Institute for International and Security Affairs.

Scott, J. W. (1998). VASAB 2010: Developing geo-governance structure for a new Baltic regionalism. In W. Toczyski (Ed.), Competition and co-operation of the Baltic regions of Denmark, Germany and Poland (pp. 75-77). Sopot: Rządowe Centrum Studiów Strategicznych.

Statistiska Centralbyran (1993). The Baltic Region. Statistics on resources, environment and economy. Stockholm: Statistiska Centralbyran.

Tillväxtverket (2016). The Baltic Sea Region Strategy for Beginners. Swedish Agency for Economic and Regional Growth. Retrieved January 5, 2019 from https://www.balticsea-region-strategy.eu/ news-room/documents-materials?task=document.viewdoc\&id=26

Toptsidou, M., \& Böhme, K. (2018). EUSBSR after 2020: Governance remastered? Final report. Ministry of Foreign Affairs of Estonia and Interreg Baltic Sea Region, Publication for the preparation of the EU Strategy for the Baltic Sea Region 9th Annual Forum. Retrieved from https://www. balticsea-region-strategy.eu/attachments/article/591006/EUSBSR-after2020_Governance-Remastered_FinalReport.pdf

Toptsidou, M., Böhme, K., Gløersen, E., Haarich, S., \& Hans, S. (2017). Added value of macro-regional strategies. Projectand programmeperspective. Finalreportof thestudy. InteractProgramme. Retrieved from http://s3platform.jrc.ec.europa.eu/documents/20182/198909/Added+value+of+the+macroregional+strategies+for+projects+and+programmes/adefa20c-8b5d-48c8-8690-1e8fdd2570cc

Umiński, S. (2012). Rozważania nad naturq, przyczynami oraz konkurencyjnościq działalności eksportowej w ujęciu regionalnym dla Polski. Gdańsk: Wydawnictwo Uniwersytetu Gdańskiego.

UN ASD (2015). Transforming our world: the 2030 Agenda for Sustainable Development. Resolution adopted by the General Assembly on 25 September 2015 (UN A/RES/70/1). Retrieved January 26, 2019 from http://www.un.org/ga/search/view_doc.asp?symbol=A/RES/70/1\&Lang=E

UN SDG (2015). UN Sustainable Development Goals, Knowledge Platform. Retrieved January 26, 2019 from https://sustainabledevelopment.un.org/?menu=130

Varjopuro, R., Soininen, N., Kuokkanen, T., Aps, R., Matczak, M., \& Danilova, L. (2015). Communique on the results of the research on blue growth in the selected international projects aimed at enhancement of maritime spatial planning in the Baltic Sea Region (BSR). Bulletin of the Maritime Institute in Gdańsk, 30(1), 72-77.

Zaucha, J. (1997). INTERREG II C in the Baltic Sea Region. Baltic Cities Bulletin, 1. 
Zaucha, J. (1998). VASAB 2010 Transnational Co-operation in the Spatial Development of the Baltic Sea Region. In U. Graute (Ed.), Sustainable Development for Central and Eastern Europe. Spatial Development in the European Context (pp. 163-179). Berlin, Heidelberg: Springer-Verlag.

Zaucha, J. (2007). Rola przestrzeni w kształtowaniu relacji gospodarczych. Ekonomiczne fundamenty planowania przestrzennego w Europie Battyckiej. Gdańsk: Uniwersytet Gdański.

Zaucha, J. (2009). Factors influencing Integration of the Baltic Sea region. With special Focus on the spatial and economic Dimension. In H. Reiter, \& J. Zweynert (Eds.), Economic Styles in the Process of EU Eastern Enlargement (pp.261-292). Schriftenreihe des Europa-Kollegs Hamburg zur Integrationsforschung, 58, Hamburg: Nomos.

Zaucha, J. (2010). Od strategii VASAB do strategii Unii Europejskiej dla Regionu Bałtyckiego. Zeszyty Naukowe Uniwersytetu Szczecińskiego, Ekonomiczne Problemy Usług, 589, 115-137.

Zaucha, J. (2013). Programming development of the Baltic Sea Region. In T. Kudłacz, \& D. Woźniak (Eds.), Programming regional development in Poland. Theory and practice (pp. 177-190). Studies of Polish Academy of Science, Committee for Spatial Economy and Regional Planning, 35, Warsaw: Polish Academy of Sciences Committee for Spatial Economy and Regional Planning.

Zaucha, J. (2014a). Sea basin maritime spatial planning: A case study of the Baltic Sea region and Poland. Marine Policy, 50, 34-45. https://doi.org/10.1016/j.marpol.2014.05.003

Zaucha, J. (2014b). The Key to governing the fragile Baltic Sea. Maritime Spatial Planning in the Baltic Sea Region and Way Forward. Riga: VASAB.

Zaucha, J. (2018). Gospodarowanie przestrzenią morską. Warszawa: Sedno.

Zaucha, J., \& Fischer, H. (2009). Spatial vision and strategies around the Baltic Sea Region. Informationen zur Raumentwicklung, 8/9, 621-628.

Zaucha, J., \& Goermar W. (1998). INTERREG I/ C and Spatial Development of the Baltic Sea Region. Retrived January 1, 2019 from http://www.geo.ut.ee/nbc/paper/zaucha.htm

Zaucha, J., \& Matczak, M. (2007). Report on Good Practices within BSR INTERREG III B and II C. Retrieved January 6, 2019 from http://commin.org/upload/Workpackage_3/Good_Practices_BSR_INTERREG.pdf

Zaucha, J., \& Szydarowski, W. (2005). Transnational Co-operation and its Contribution to Spatial Development and EU Enlargement. The Case of INTERREG III B In Northern Poland. Informationen zur Raumentwicklung, 11/12, 731-740.

Zaucha, J., \& Török, L. (2011). A Balti-stratégia mint a makroregionális egyűttműködés elsö példája. Területi Statisztika, 14(51), 644-655.

\section{Annex: Opinions of the MP Tadeusz Aziewicz (interview on February 10, 2019)}

The EU macro-regional Strategy for the Baltic Sea Region is an important initiative that has engaged very diverse countries in combined operations, creating significant added value which strengthens the competitiveness of, not only the region, but also the entire Community.

Celebrating the tenth anniversary of approving the Strategy and appreciating its positive effects, it is worth considering a strengthening of the effectiveness of the activities which have been carried out so far.

It seems that the work on the Strategy is too dominated by experts and executive authorities of individual countries. The Strategy, de facto, does not exist in the collective consciousness and that concerns both the regional and national dimensions. In discussions which are taking place in the Parliament of the Republic of Poland, it is present only occasionally.

I have an impression that good cooperation of experts may create a false impression regarding the knowledge and acceptance of the provisions of the Strategy by the citizens of member 
countries and their representatives on various levels. The fact that the document does not evoke more emotions is not its strong point, rather it is a result of limiting the participants of the debate to a rather narrow group.

Strengthening awareness of the Strategy is worth considering and it requires making additional public relations efforts and incorporating the Strategy into political discussions, also with the involvement of national parliamentarians who should act as a natural transmission belt between the executive and citizens.

This should result in greater understanding and support for the processes being carried out and for the mobilisation of member countries whose deeper involvement may be crucial for increasing the added value resulting from cooperation in the scope described in the Strategy. 